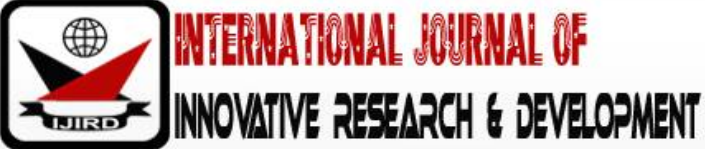

ISSN 2278 - 0211 (Online)

\section{Impact of Credit Management on the Operational Performance of Productive Firms in the Nigerian Economy: A Study of Most Selected Productive Organizations in Nigeria 2007-2016}

\begin{tabular}{|}
\hline Ehiriudu Jude Alaoma \\
Lecturer, Department of Accountancy School of Financial Studies, \\
Institute of Management and Technology (IMT), Nigeria \\
Ugwuta Emmanuel Emeka, \\
Lecturer, Department of Accountancy, School of Financial Studies, \\
Institute of Management and Technology (IMT), Enugu, Nigeria \\
Abia Oluchi Patience \\
Lecturer, Department of Accountancy, School of Financial Studies, \\
Institute of Management and Technology (IMT), Nigeria
\end{tabular}

\begin{abstract}
:
The study appraised the impact of credit management on the operational performance of productive firms in the economy focusing on selected productive organizations in Nigeria namely Nigeria Breweries Plc, Guinness Nigeria Plc and Nestle Nigeria Plc. The objectives of this study include the following; to ascertain the effects of debt ratio on the return on asset ratio of the productive firms in Nigeria. The main purpose of this study is to find the influence of account receivable ratio on the return on asset ratio of the Nigerian productive firms and to determine the effect of account payable ratio on the return on asset for the same. The study used ex - post facto as design while the analytical tools used were unit root test, descriptive statistics and random panel regression model. Debt ratio does not have found significant associated on the return on asset ratio. Moreover, return on asset ratio does not found significantly associated with the account receivable ratio. The return on asset ratio does not significantly affected on that account payable ratio. The study concluded that for Nigerian brewery Plc the return on asset ratio and debt ratio were stationary at first difference while account receivable ratio and account payable ratio became stationary at second difference. The study recommended that to encourage credit facilities in a brewery firm the sales department of the firm must have thorough understand of the credit policy which will encourage the customers or client to accept their credit facilities without being bias rather based on returns or yield of profits. Companies should increase the rate of credit sales based on credit behavior and trustworthy of customers only despite the fact that credit sales are a marketing tool to maintain or expand sales.
\end{abstract}

Keywords: Accounts receivable, accounts payable, credit policies, credit management

\section{Introduction}

\subsection{Background of the Study}

Being one of the important activities, credit management cannot be overlooked by any company irrespective of its nature. Without immediate financial backing, it ensures that customers will pay for the products delivered. An optimum level of credits can be managed through this process by which firm can run efficiently (Pandey, 2013). Many aspects like credit analysis, credit rating, credit classification and credit reporting can be done through this. Credit sales can be managed by this means (Nwaezeaku, 2007). The higher the amount of accounts receivables and their age, the higher the finance costs incurred to maintain them. If these receivables are not collectible on time and urgent cash needs arise, a firm may result to borrowing and the opportunity cost is the interest expense paid.

Solomon and Pringle, (2009) opined that credit management greatly influences the success or failure of organizations. This is because the failure of these organizations is influenced to a large extent by the quality of credit decisions and thus the quality of the risky assets. He further notes that, credit management provides a leading indicator of the quality of organizations credit portfolio. A key requirement by which intelligently and efficiently credit management can be done. 
As per Smith (2015), with sales credit management initiates and ends with final payment. It ensures that borrower will be able to make scheduled payments. It mainly concerned with debtors and financing debts. It safe guards the investments in debtors and also optimizes operational cash flows.

\subsection{Research Problem}

Organizational stability and continuing operational performance can be ensured by credit management (Pandey, 2013). The relaxation sign of credit standards increases the probability of bad debts (Western, and Brigham, 2006). Finally, it affects customer relations. On that basis, it is simply good business to put credit management at the front end by managing it strategically based on track records of payment of the customer. From the ongoing, credit management has requisite effect on a firm's debt ratio, liquidity ratio and account receivable ratio. This necessitates the essence of this study on the impact of credit management on the operational performance of productive firms in the economy.

\subsection{Objectives of the Study}

The broad objective of this study is to appraise the impact of credit management on the operational performance of productive firms in the economy focusing on selected productive organizations in Nigeria.

The specific objectives of this study include the following:

- To ascertain the effects of debt ratio on the return on asset ratio of the productive firms in Nigeria.

- To examine the impact of account receivable ratio on the return on asset ratio of the productive firms in Nigeria.

- To determine the effect of account payable ratio on the return on asset ratio of the productive firms in Nigeria.

\subsection{Research Questions}

- What are the effects of debt ratio on the return on asset ratio of the productive firms in Nigeria?

- What are the impacts of account receivable ratio on the return on asset ratio of the productive firms in Nigeria? 3. What are the effects of account payable ratio on the return on asset ratio of the productive firms in Nigeria?

\subsection{Research Hypotheses}

- Debt ratio does not have a significant effect on the return on asset ratio of the productive firms in Nigeria.

- Account receivable ratio does not have a significant effect on the return on asset ratio of the productive firms in Nigeria.

- Account payable ratio does not have a significant effect on the return on asset ratio of the productive firms in Nigeria.

\subsection{Significance of the Study}

This study will be of enormous benefit to the productive firms in Nigeria in Nigeria in that they will be enlightened on the concepts of credit management and will also suggest for them on the diverse credit management strategies for enhancing or promoting operational performance. challenges.

The recommendations of the study will equally suggest for these firms on how to redress their credit management

The general populace will get to understand the concepts of credit management as well as how it can be implemented in their diverse businesses.

Students and other researchers will as well widen their scope and horizon from the information contained in this study.

\subsection{Scope of the Study}

This study is centered impact of credit management on the operational performance of the productive firms in Nigeria covers selected firms in Nigeria namely; Nigerian Breweries Plc, Guinness Nigeria Plc and Nestle Plc The study covered from 2007 to 2017.

The researcher also encountered difficulty in gathering the requisite information necessary to construct the literature review. The researcher was able to overcome this challenge by consulting diverse textbooks in credit management as well as consulting journals in the same topic. Account payable ratio is a ratio that measures the speed with which a company pays its suppliers.

\subsection{Return on Assets}

Return on assets (ROA) is an indicator of how profitable a company is relative to its total assets.

\section{Review of Related Literature}

\subsection{Conceptual Review}

\subsubsection{Meaning of Credit Management}

Credit management is another vital and sensitive parts of business management in Nigeria. The volatility of business and risks associated with business activities in Nigeria and the World globally had instilled fears among the givers of these credit facilities. 
Nwaezeaku, (2007) defines credit management as the means by which an entity manages its credit sales. It is a prerequisite for any business concerns dealing with credit transactions since it is impossible to have a zero credit or default risk. According to (Emery, 2010) explained that credit is the trust or understanding which allows one party to provide money or resources to another party where the second party does not repay immediately and promises to pay later. He sees the management of credit as a process of organizing credit activities based on credit policy, credit worthiness and credit behavior before. David and Samuel, (2012) stated that organization should employ seasoned and trained credit analyst to measure, manage credit and avoid bad debts. This is in a bid of solving the problem of a firm's bad debts and improved cash flow in any organization. Solomon and Pringle (2009) narrows it down by explaining that credit is extended by a creditor also known as a lender and to a debtor also known as a borrower.

\subsubsection{Effect of Credit Management on Operational Performance}

Collection and control of payments can be done through credit management. It reduces the chance of getting capital locked with the debtors and also reduces the chance of getting into bad debts. With additional credit, companies can be tempted for some competitive markets. For many companies' bad debts cause losses. Visible reduction of Profit and Loss Account happened through the writing-off of bad debt. Generally, it can be measured separately and can be mixed with other charges. Separate interest cost can be charged for debtors. Redesign and documenting a credit policy are involved in successful management of accounts receivables (Foulks, 2008). Sloppy credit standards and inappropriate credit policies often give birth to liquidity and inadequate working capital problems. A proper credit policy helps to manage valuable asset, the customers (Western and Brigham, 2006). Kakuru, (2011) proposes that a credit policy creates a common set of goals for the organization and recognizes the credit and collection department as an important contributor to the organization's strategies. If the credit policy is correctly formulated, carried out and well understood at all levels of the financial institution, it allows management to maintain proper standards of the bank loans to avoid unnecessary risks and correctly assess the opportunities for business development.

\subsubsection{The Concept of Debt Ratio}

According to Adewurumi (2011), a clear distinction is there between surplus economic units and the deficit economic units. This is the reason why transfer of funds from savers to investors is being required. Banking sector is such a type of institution. According to Egginton (2010), it displayed surplus economic units along with the rate and shape of the economic development. How much funds need to be allocated to investors can be ascertained through this where the probability of full payment is present. It can be both long-term and short-term. It is the amount of company's assets which is financed by debt. The ratio between total debts to its total assets expresses debt ratio. It reflects the amount of leverage being used by a company.

\subsubsection{The Concept of Liquidity Ratio}

The quantity of capital that is accessible for investment. Now-a-days capital can be of credit, not cash. Bank Liquidity simply means the ability of the bank to maintain sufficient funds to pay for its maturing obligations. It is the bank's ability to immediately meet cash, cheques, other withdrawals obligations and legitimate new loan demand while abiding by existing reserve requirements. Pandey (2005) defined liquidity as the degree of convertibility to cash or the ease with which any asset can be converted to cash (sold at a fair market price).

Liquidity management therefore involves the strategic supply or withdrawal from the market or circulation the amount of liquidity consistent with a desired level of short-term reserve money without distorting the profit-making ability and operations of the bank. It relies on the daily assessment of the liquidity conditions in the banking system, so as to determine its liquidity needs and thus the volume of liquidity to allot or withdraw from the market. The liquidity needs of the banking system are usually defined by the sum of reserve requirements imposed on banks by a monetary authority.

Liquidity management is among the four cardinal decision areas of financial management that requires careful handling and planning for a business enterprise to be successful and profitable (Pandey, 2005).

Interestingly, working capital component of a firm's financial management function deals with the liquidity aspects of the entity and hence fundamental for the effective and efficient operations as well as sustain its going concern status.

Liquidity and its management determine to a great extent the growth and operational performance of a firm. This is because either inadequate liquidity or excess liquidity may be injurious to the smooth operations of the organization. It is worth mentioning from the outset that working capital and liquidity are used in this review to mean one and the same thing and relates to the management of current assets and current liabilities of an enterprise. This synonym is based on the fact that working capital ratios are the most commonly accepted measures of liquidity.

Liquidity management determines to a large extent the level of profit to be realized and improvement to shareholders wealth (Owolabi and Obida, 2012). This is because, for a firm to survive in business it must remain liquid as failure to meet its obligation in due course may result to bad credit rating by the short-term creditors; reduction in the value of goodwill in the market that may ultimately lead to liquidation. A good financial management policy should seek to maintain adequate liquidity in order to meet its short-term maturing obligations without impairing operational performance. Unfortunately, the principal focus of most organizations is profit maximization while the need to efficiently manage the liquid assets of the firm is ignored. This approach is justified by the belief that operational performance and liquidity are conflicting goals.

However, a firm can only pursue one at the expense of the other, in consonance with the theory of liquidity and operational performance trade-off. Nwaezeku, (2008) advised that a firm should maintain a balance between liquidity and 
operational performance while conducting its daily operations. Because whether it is a surplus situation or inadequate, liquidity would directly affect operational performance.

Liquidity therefore plays a significant role in the successful functioning of a business firm. A study of liquidity is of major importance to both internal and external analysts because of its close relationship with day to day operations of a business. The dilemma in liquidity management is to achieve a desired trade-off between liquidity and operational performance. However, the liquidity requirement of a firm depends on the nature of the firm and there is no specific rule on determining the optimal level of liquidity that a firm can maintain in order to ensure positive impact on its operational performance.

Liquidity management has been an area of major concern to owners and managers of business entities all over the world, as efforts have been made to devise strategies on how the day to day operations can be managed in order to meet their financial obligations as at when they fall due.

Liquidity ratios, according to Majeed, Makki, Saleem and Aziz (2013), attempt to measure a company's ability to pay off its short-term debt obligations. This is done by comparing a company's most liquid assets, those that can be easily converted to cash, with its short-term liabilities

Liquidity ratio expresses a company's ability to repay short-term creditors out of its total cash. It is the result of dividing the total cash by short-term borrowings. It shows the number of times short-term liabilities are covered by cash. If the value is greater than 1.00 , it means fully covered.

The formula is the following:

$\mathrm{LR}=$ liquid assets $/$ short-term liabilities

According to Nasr and Raheman (2007) a liquidity ratio is an indicator of whether a company's current assets will be sufficient to meet the company's obligations when they become due.

The liquidity ratios include the current ratio and the acid test or quick ratio. The current ratio and quick ratio are also referred to as solvency ratios. Working capital is an important indicator of liquidity or solvency, even though it is not technically a ratio.

Liquidity ratios sometimes include the accounts receivable turnover ratio and the inventory turnover ratio. These two ratios are also classified as activity ratios.

\subsubsection{The Concept of Account Payable Ratio}

Account payable is a special type of entry which shows the pay off a short-term debt to its creditors (Orjih and Okafor,2012). It found under the heading of current liabilities. It must be paid back within a given period of time. The ability to manage equivalent documents and information can be tracked by the accounts payable (Okolie, 2012). It reduces the chance risk of losing documents, enhances document search flexibility, improves the invoices and accounts payable information. It is no longer needed for any organization. It is not only needed to gain accounts payable information but helps to analyze and review transactions, adopt new technologies.

As per Anthony (2013), the accounts payable turnover ratio is the short-term liquidity measure that can quantify the rate at which suppliers can be paid off.

The ability of a firm to pay off its accounts payable is being reflected by the accounts payable turnover ratio. This is a type of liquidity ratio. How many times a company can pay off its average account payable balance in a year can be reflected through this.

This ratio helps creditors analyze the liquidity of a company by gauging how easily a company can pay off its current suppliers and vendors. Companies that can pay off supplies frequently throughout the year indicate to creditor that they will be able to make regular interest and principle payments as well (Afolabi, 2011).

Vendors also use this ratio when they consider establishing a new line of credit or floor plan for a new customer. For instance, car dealerships and music stores often pay for their inventory with floor plan financing from their vendors. Vendors want to make sure they will be paid on time, so they often analyze the company's payable turnover ratio.

\subsection{Theoretical Framework of the Study}

The theoretical framework of this study is based on the liquidity preference theory and credit risk theory.

\subsection{Liquidity Preference Theory}

This theory suggests that the premium demanded for parting with cash raises as the term for getting the cash decreases. The rate in the increase of this premium amount slows down with the increase term. In financial trading, this theory is expressed as forward rates should exceed the future spot rates. This theory is also known as liquidity preference hypothesis. Liquidity preference theory intimates the idea that investors demand a premium for securities with longer maturities, which entail greater risk, because they would prefer to hold cash, which entails less risk. The more liquid an investment, the easier it is to sell quickly for its full value.

According to Nilsen, (2012), the demand for liquidity is determined by three motives the transactions motive: people prefer to have liquidity to assure basic transactions, for their income is not constantly available. The amount of liquidity demanded is determined by the level of income: the higher the income, the more money demanded for carrying out increased spending. The precautionary motive, people prefer to have liquidity in the case of social unexpected problems that need unusual costs.

The amount of money demanded for this purpose increases as income increases. Speculative motive: people retain liquidity to speculate that bond prices will fall. When the interest rate decreases people demand more money to hold until the interest rate increases, which would drive down the price of an existing bond to keep its yield in line with 
the interest rate (Ojeka, 2012). Thus, the lower the interest rate, the more money demanded and vice versa. A financial institution that lends out credit to borrowers may face liquidity problem especially if the borrowers are not able to pay the loans on time. This may prevent the firms from investing in profitable projects that promises higher returns in future. According to this theory, a firm needs to hold more cash for investment, it is therefore important for the firm to mitigate the level of credit risk by ensuring that borrowers are credit worthy before giving out credit.

\subsection{Credit Risk Theory}

Bhunia, (2010) posit that credit risk theory is the first readily available portfolio model for evaluating credit risk. The credit risk approach enables a company to consolidate credit risk across its entire organization, and provides a statement of value-at-risk (VaR) due to credit caused by upgrades, downgrades, and defaults. Credit risk model is useful to all firms that are exposed to credit risk in the course of their business. According to this theory, a firm should develop a methodology to quantify credit risk across a broad range of instruments, including traditional loans, commitments and letters of credit; fixed income instruments; commercial contracts such as trade credits and receivables; and market-driven instruments such as swaps, forwards and other derivatives.

Eugene, (2012) explains that credit risk statistical concepts like probability, means, and standard deviation, correlation, and concentrations were developed with three objectives which include to develop a Value at Risk (VAR) framework applicable to all the institutions worldwide that carry the credit risks in the course of their businesses, develop a portfolio view showing the credit event correlation which can identify the costs of concentrations and the benefits of diversification in a mark to market framework and to apply it in making investment decisions and risk mitigating actions that is determining the risk based credit limits across the portfolio, and rational risk based capital allocations. According to Foulks (2008), an integrated credit risk management system should be there in order to track the changes in debt value caused by changes in obligor credit quality. This model is very useful to track the changes caused by possible default events along with positive and negative sides of credit quality. A recovery rate is generally being adopted in the case of portfolio value.

This distribution gives us two measures of credit risk which are standard deviation and percentile level. There are various applications which are to reduce the portfolio risk by reevaluating obligors having the largest absolute size arguing that a single default among these would have the greatest impact, reevaluate obligors having the highest percentage level of risk arguing that these are the most likely to contribute to portfolio losses, reevaluate obligors contributing the largest absolute amount of risk arguing that these are the single largest contributors to portfolio risk (Kakuru, 2011).

\subsection{Empirical Review}

Adigwe (2010) studied credit management on liquidity and operational performance positions of a manufacturing company in Nigeria. His objectives were to determine the extent to which credit policy can affect operational performance management in manufacturing companies in Nigeria, to determine the significant correlation between liquidity position and debtor's turnover of the company in Nigeria and to determine there is any relationship between liquidity management and corporate operational performance. A statistical nonparametric test called Analysis of Variance (ANOVA) was used because it measures or tests three or more independent means. The study found out that effective management of credit grant has a positive relationship with the operating profit of the companies in the corporate organizations.

Four Nigerian manufacturing companies have been studied by Ojeka (2012) on the basis of annual reports and accounts as well as questionnaire. The finding revealed that a desirable level of liquidity can be seen if the credit policy is favourable. A regular monitor on liquidity position and operational performance helps to perform better for firms. A working capital management-based study had been done on Nigeria by Uremadu, Egbido and Enyi (2012). A cross sectional time series-based dataset had been analyzed for a time period of 2005 - 2006. Debtors collection period has been used as proxy or credit policy. A non-significant relationship had been observed with the relationship of debtors" collection period with the level of corporate operational performance cum liquidity among quoted companies in Nigeria. Kenyan pharmaceutical manufacturing companies-based studies had been conducted by Kalunda (2012) on credit risk management practices. Debt collectors, letter of credit, and credit insurance and factor of debt had been seen as widely used credit risk management practices.

\section{Research Methodology}

\subsection{Research Design}

Mmamel and Samuel, (2010) describes research design as the arrangement of conditions for collection and analysis of data in a manner that aims to combine relevance to the research purpose with economy in procedure.

Therefore, the research design to be adopted for this study is ex post facto research design.

The choice of this research design is based on the fact that the researcher will make use of secondary data to carry out this study. Moreover, the researcher's choice of this technique is based not only on its computational simplicity, but also as a result of its optimal properties such as, linearity, unbiasedness, minimum variance, zero mean value of the random terms, etc. 


\subsection{Sources of Data}

This study is a secondary research, as such; secondary source of data was utilized to carry out this research. The main sources of data include: financial report of selected quoted productive firms in Nigeria in Nigeria.

\subsection{Sample Size}

The sample size of the study consists of Nigerian Breweries Plc, Guinness Nigeria Plc and Nestle Nigeria Plc.

\subsection{Model Specification}

A multiple regression models was used to test the effect of the selected credit management variables (independent variables) on the operational performance of the selected firms (dependent variable)

Thus, the model is represented in a functional form as follow:

$$
\mathrm{ROAR}=\mathrm{F}(\mathrm{DR}, \mathrm{ARR}, \mathrm{APR})
$$

Where:

ROAR =return on asset ratio (it is used as a proxy for operational performance)

$\mathrm{DR}=$ Debt ratio (it is used as a proxy for credit management)

$\mathrm{ARR}=\mathrm{Account}$ receivable ratio (it is used as a proxy for credit management)

$\mathrm{APR}=$ account payable ratio (it is used as a proxy for credit management)

In a linear regression form, it will become:

$\mathrm{ROAR}=\beta \mathrm{O}+\beta_{1} \mathrm{DR}+\beta_{2} \mathrm{LR}+\beta_{3} \mathrm{APR}+\mu$

$\beta \mathrm{o}=$ Constant Term

$\beta_{1}=$ Coefficient of Debt Ratio

$\beta_{2}=$ Coefficient of Account receivable ratio

$\beta_{3}=$ Coefficient of account payable ratio

$\mu=$ Error Term

\subsection{Description of the Variables}

The dependent variable for this study is operational performance which is proxied by return on asset ratio while the independent variable is credit management which is proxied by Debt Ratio, liquidity ratio and account payable ratio.

\subsection{Dependent Variable}

\subsubsection{Return on Assets}

Return on assets (ROA) is an indicator of how profitable a company is relative to its total assets. ROA gives an idea as to how efficient management is at using its assets to generate earnings. Calculated by dividing a company's annual earnings by its total assets, ROA is displayed as a percentage.

Return on Assets

$$
=\quad \text { Payables }(\mathrm{PB})
$$

Cost of Sales (COS)

\subsection{Independent Variable}

\subsubsection{Debt Ratio}

The debt ratio is defined as the ratio of total - long-term and short-term - debt to total assets, expressed as a decimal or percentage. It can be interpreted as the proportion of a company's assets that are financed by debt.

Debt Ratio $=$

\subsubsection{Account Receivable Ratio}

Total Liabilities (TL)

Total Assets (TA)

The calculation of a company's available cash and marketable securities against outstanding debt

Account receivable Ratio

$=\quad$ Net Credit Sales(NCS)

Average Account Receivable (AAR)

\subsubsection{Account Payable Ratio}

The accounts payable turnover ratio is a short-term liquidity measure used to quantify the rate at which a company pays off its suppliers.

Account Payable Ratio =

Payables (PB)

Cost of Sales (COS) 


\subsection{Analytical Technique}

In order to achieve the objective of this study, data will be analyzed using unit root test, descriptive statistics and random panel regression model. Unit root test will be used to measure the stationarity properties of the variables, descriptive statistics will be used to ascertain the individual characteristics of the variables while random panel regression model will be used to determine how the independent variables affect the dependent variables

\section{Data Presentation and Analysis}

The main objective of this research work is to investigate the effect of credit management on the operational performance of the productive firms in Nigeria in Nigeria. The chapter focused on data presentation, analysis and interpretation of results. In order to provide answers to the research questions stated in chapter one, test of hypothesis is carried out. The study had two variables which is independent and dependent variables.

The independent variables consist of the following: Debt Ratio (DR), Account receivable Ratio (ARR), Account Payable Ratio (APR). Dependent variable is thus, Return on assets (RAR).

In the analysis, Descriptive statistics which comprise of mean, standard deviation and Jacque - Berra and Correlation analysis were employed as a tool to get a reasonable answer to the objectives in chapter one.

\begin{tabular}{|c|c|c|c|c|c|c|c|}
\hline YEARS & $\begin{array}{c}\text { PAT } \\
\left(\mathbf{N}^{\prime} 000\right)\end{array}$ & $\begin{array}{c}\text { TA } \\
\left(\mathbf{N}^{\prime} 000\right)\end{array}$ & $\begin{array}{c}\text { TL } \\
\left(\mathbf{N}^{\prime} \mathbf{0 0 0}\right)\end{array}$ & $\begin{array}{c}\text { PB } \\
\left(\mathbf{N}^{\prime} \mathbf{0 0 0}\right)\end{array}$ & $\begin{array}{c}\text { COS } \\
\left(\mathbf{N}^{\prime} \mathbf{0 0 0}\right)\end{array}$ & $\begin{array}{c}\text { NCS } \\
\left(\mathbf{N}^{\prime} \mathbf{0 0 0}\right)\end{array}$ & $\begin{array}{c}\text { AAR } \\
\text { (N'000) }\end{array}$ \\
\hline 2007 & 18,942 & 90,126 & 40,170 & 201,111 & 75,610 & 2,837 & 4,865 \\
\hline 2008 & 25,701 & 104,412 & 12,475 & 142,024 & 101,010 & 2,901 & 4,916 \\
\hline 2009 & 27,910 & 106,987 & 42,344 & 205,516 & 98,641 & 1,200 & 3,094 \\
\hline 2010 & 30,332 & 114,389 & 48,359 & 125,203 & 98,003 & 3,150 & 5,146 \\
\hline 2011 & 38,409 & 196,936 & 51,944 & 141,211 & 87,048 & 3,779 & 5,841 \\
\hline 2012 & 38,043 & 253,634 & 67,398 & 97,451 & 78,410 & 4,120 & 6,094 \\
\hline 2013 & 43,080 & 252,760 & 75,021 & 12,247 & 132,136 & 4,570 & 6,741 \\
\hline 2014 & 42,520 & 349,677 & 87,266 & 10,024 & 130,788 & 3,220 & 5,048 \\
\hline 2015 & 38,056 & 356,219 & 183,897 & 21,000 & 63,551 & 2,380 & 4,371 \\
\hline 2016 & 28,417 & 367,146 & 201,232 & 22,195 & 60,162 & 6,551 & 8,831 \\
\hline
\end{tabular}

Table 1: Raw Data of Nigerian Breweries Plc

Source: Financial Statement of Nigerian Breweries Plc

\begin{tabular}{|c|c|c|c|c|}
\hline YEARS & DR & ARR & APR & RA \\
\hline 2007 & 0.4457093 & 0.58314 & 2.6598466 & 0.2101724 \\
\hline 2008 & 0.1194786 & 0.59011 & 1.406039 & 0.2461499 \\
\hline 2009 & 0.3957864 & 0.38784 & 2.0834744 & 0.2608728 \\
\hline 2010 & 0.4227592 & 0.61212 & 1.2775425 & 0.2651654 \\
\hline 2011 & 0.2637608 & 0.64697 & 1.6222199 & 0.1950329 \\
\hline 2012 & 0.2657294 & 0.67607 & 1.2428389 & 0.1499917 \\
\hline 2013 & 0.2968072 & 0.67794 & 0.0926848 & 0.1704384 \\
\hline 2014 & 0.2495617 & 0.63787 & 0.0766431 & 0.1215979 \\
\hline 2015 & 0.516247 & 0.54449 & 0.3304433 & 0.1068332 \\
\hline 2016 & 0.548098 & 0.74181 & 0.3689206 & 0.0773997 \\
\hline
\end{tabular}

Table 2: Derivatives of the Raw Data for Nigeria Breweries Plc

Source: Computation of Financial Statement of Nigerian Breweries Plc Field Work 2019

\begin{tabular}{|c|c|c|c|c|c|c|c|}
\hline 58 & $\begin{array}{c}\text { PAT } \\
\left(N^{\prime} 000\right)\end{array}$ & $\begin{array}{c}\text { TA } \\
\text { (N'000) }\end{array}$ & $\begin{array}{c}\text { TL } \\
\left(\mathrm{N}^{\prime} \mathbf{0 0 0}\right)\end{array}$ & $\begin{array}{c}\text { PB } \\
\left(N^{\prime} 000\right)\end{array}$ & $\begin{array}{c}\text { COS } \\
\left(N^{\prime} 000\right)\end{array}$ & $\begin{array}{c}\text { NCS } \\
\text { (N'000) }\end{array}$ & $\begin{array}{c}\text { AAR } \\
\left(\mathbf{N}^{\prime} \mathbf{0 0 0}\right)\end{array}$ \\
\hline 2007 & 10691 & 71809 & 47365 & 272383 & 52564 & 1,517 & 3,125 \\
\hline 2008 & 11860 & 73191 & 72183 & 79557 & 74562 & 2,246 & 3,669 \\
\hline 2009 & 13541 & 73868 & 60417 & 205516 & 88734 & 4,885 & 6,885 \\
\hline 2010 & 13736 & 82558 & 64217 & 155003 & 98694 & 3,992 & 5,997 \\
\hline 2011 & 17927 & 82558 & 75070 & 30000 & 120361 & 1,863 & 2,778 \\
\hline 2012 & 14214 & 92227 & 160185 & 45000 & 127222 & 2,685 & 4,554 \\
\hline 2013 & 11863 & 106009 & 140400 & 9000 & 132136 & 2,785 & 4,887 \\
\hline 2014 & 9573 & 121060 & 177794 & 24670 & 1307888 & 3,541 & 5,568 \\
\hline 2015 & 7794 & 122246 & 73905 & 21624 & 149736 & 4,214 & 6,325 \\
\hline 2016 & 2015 & 136992 & 95331 & 17000 & 178218 & 5,866 & 7,889 \\
\hline
\end{tabular}

Table 3: Raw Data of Guinness Nigeria Plc

Source: Financial Statement of Guinness Nigeria Plc

Field work 2019 


\begin{tabular}{|c|c|c|c|c|}
\hline YEARS & DR & ARR & APR & RA \\
\hline 2007 & 0.659597 & 0.58314 & 5.1819306 & 0.1488811 \\
\hline 2008 & 0.9862278 & 0.59011 & 1.0669912 & 0.1620418 \\
\hline 2009 & 0.8179049 & 0.38784 & 2.3160908 & 0.1833135 \\
\hline 2010 & 0.777841 & 0.61212 & 1.5705413 & 0.16638 \\
\hline 2011 & 0.9093001 & 0.64697 & 0.2492502 & 0.2171443 \\
\hline 2012 & 0.1754909 & 0.67607 & 0.3537124 & 0.1541197 \\
\hline 2013 & 1.3244159 & 0.67794 & 0.0681116 & 0.1119056 \\
\hline 2014 & 1.4686436 & 0.63787 & 0.0188625 & 0.0790765 \\
\hline 2015 & 0.6045597 & 0.54449 & 0.1444142 & 0.0637567 \\
\hline 2016 & 0.6958874 & 0.74181 & 0.0953888 & 0.0147089 \\
\hline
\end{tabular}

Table 4: Derivatives of the Raw Data for Guinness Nigeria Plc

Source: Computation of Financial Statement Of Guinness Nigeria Plc Field Work 2019

\begin{tabular}{|c|c|c|c|c|c|c|c|}
\hline YEARS & $\begin{array}{c}\text { PAT } \\
\text { (N'000) }\end{array}$ & $\begin{array}{c}\text { TA } \\
\left(\mathbf{N}^{\prime} \mathbf{0 0 0}\right)\end{array}$ & $\begin{array}{c}\text { TL } \\
\left(N^{\prime} 000\right) \\
\end{array}$ & $\begin{array}{c}\text { PB } \\
\left(N^{\prime} 000\right)\end{array}$ & $\begin{array}{c}\text { COS } \\
\left(\mathrm{N}^{\prime} \mathbf{0 0 0}\right)\end{array}$ & $\begin{array}{c}\text { NCS } \\
\left(N^{\prime} 000\right)\end{array}$ & $\begin{array}{c}\text { AAR } \\
\text { (N'000) }\end{array}$ \\
\hline 2007 & 188 & 71809 & 13100 & 18493 & 22504 & 1,454 & 3,656 \\
\hline 2008 & 201 & 739191 & 13656 & 17388 & 44515 & 1,809 & 3,868 \\
\hline 2009 & 285 & 73868 & 12704 & 9908 & 57799 & 2,706 & 4,060 \\
\hline 2010 & 2800 & 82558 & 9999 & 4794 & 24694 & 3,241 & 5,514 \\
\hline 2011 & 2172 & 92227 & 5374 & 1616 & 70362 & 1,663 & 2,374 \\
\hline 2012 & 2897 & 106009 & 4274 & 1072 & 27244 & 4,285 & 6,300 \\
\hline 2013 & 2327 & 121060 & 999 & 561 & 44136 & 5,112 & 6,868 \\
\hline 2014 & 2105 & 132328 & 706 & 313 & 130788 & 1,551 & 3,558 \\
\hline 2015 & 3222 & 122246 & 424 & 401 & 52736 & 6,223 & 8,258 \\
\hline 2016 & 4105 & 136992 & 5389 & 5201 & 105122 & 7,232 & 9,125 \\
\hline
\end{tabular}

Table 5: Raw Data of Nestle Nigeria Plc

Source: Financial Statement of Nestle Nigeria Plc

\begin{tabular}{|c|c|c|c|c|}
\hline YEARS & DR & ARR & APR & RA \\
\hline 2007 & 0.1824284 & 0.39770 & 0.821765 & 0.0026181 \\
\hline 2008 & 0.0184743 & 0.46768 & 0.3906099 & 0.0002719 \\
\hline 2009 & 0.1719825 & 0.66650 & 0.1714217 & 0.0038582 \\
\hline 2010 & 0.1211149 & 0.58777 & 0.1941362 & 0.0339156 \\
\hline 2011 & 0.0582693 & 0.70050 & 0.0229669 & 0.0235506 \\
\hline 2012 & 0.0403173 & 0.68015 & 0.0393481 & 0.0273279 \\
\hline 2013 & 0.0082521 & 0.74432 & 0.0127107 & 0.0192219 \\
\hline 2014 & 0.0053352 & 0.43591 & 0.0023932 & 0.0159074 \\
\hline 2015 & 0.0034684 & 0.75357 & 0.0076039 & 0.0263567 \\
\hline 2016 & 0.0393381 & 0.79254 & 0.0494758 & 0.0299653 \\
\hline
\end{tabular}

Table 6: Derivatives of the Raw Data for Nestle Nigeria Plc

Source: Computation from Financial Statement of Nestle Nigeria Plc

Field Work 2019

4.1. Normality Test

\begin{tabular}{|c|c|c|c|c|}
\hline & ROAR & DR & ARR & APR \\
\hline Mean & 0.755356 & 0.369193 & 0.944391 & 0.798466 \\
\hline Median & 0.262555 & 0.304275 & 0.893397 & 0.333946 \\
\hline Maximum & 5.305932 & 0.903420 & 1.621691 & 2.274686 \\
\hline Minimum & 0.129170 & 0.143730 & 0.676646 & 0.079327 \\
\hline Std. Dev. & 1.602153 & 0.219367 & 0.286885 & 0.835826 \\
\hline Skewness & 2.646526 & 1.498581 & 1.383584 & 0.929796 \\
\hline Kurtosis & 8.048261 & 4.594688 & 4.112879 & 2.084065 \\
\hline Jarque-Bera & 22.29223 & 4.802505 & 3.706549 & 1.790425 \\
\hline Probability & 0.000014 & 0.090604 & 0.156723 & 0.408521 \\
\hline Sum & 7.553556 & 3.691930 & 9.443911 & 7.984657 \\
\hline Sum Sq. Dev. & 23.10205 & 0.433097 & 0.740726 & 6.287451 \\
\hline Observations & 10 & 10 & 10 & 10 \\
\hline
\end{tabular}

Table 7: Descriptive Statistics (Nigerian Brewery Plc) 
The study conducted the descriptive statistics of the relevant variables involved. Table 4.2 illustrates vividly these statistics. It shows total number of observations, mean, median, maximum, minimum, standard deviation, skewness, kurtosis and Jarque-Bera. The dependent variable which is return on asset ratio shows a minimum value of 0.129170 and a maximum value of 5.305932. The mean value of the dependent variable is 0.755356 and the standard deviation is 1.602153. This implies that there was high fluctuation in return on asset ratio for the years. It can be observed from Table 4.2 that all the variables have positive average values (means). It can be observed also that all the variables show signs of positive skewness while all the variables except account payable ratio have high kurtosis, therefore they are leptokurtic.

\begin{tabular}{|c|c|c|c|c|}
\hline & ROAR & DR & ARR & APR \\
\hline Mean & 1.961074 & 0.328643 & 1.360415 & 0.986397 \\
\hline Median & 2.222784 & 0.283315 & 1.324094 & 0.613741 \\
\hline Maximum & 3.225994 & 0.639310 & 1.558861 & 4.611446 \\
\hline Minimum & 0.242115 & 0.147532 & 1.214107 & 0.383124 \\
\hline Std. Dev. & 0.975762 & 0.158551 & 0.125050 & 1.285913 \\
\hline Skewness & -0.883358 & 0.709806 & 0.392311 & 2.573395 \\
\hline Kurtosis & 2.690277 & 2.388279 & 1.741368 & 7.819777 \\
\hline Jarque-Bera & 1.340507 & 0.995625 & 0.916578 & 20.71654 \\
\hline Probability & 0.511579 & 0.607859 & 0.632365 & 0.000032 \\
\hline Sum & 19.61074 & 3.286432 & 13.60415 & 9.863973 \\
\hline Sum Sq. Dev. & 8.569004 & 0.226245 & 0.140738 & 14.88216 \\
\hline Observations & 10 & 10 & 10 & 10 \\
\hline
\end{tabular}

Table 8: Descriptive Statistics (Guinness Nigeria Plc)

The study conducted the descriptive statistics of the relevant variables involved. Table 4.2 illustrates vividly these statistics. It shows total number of observations, mean, median, maximum, minimum, standard deviation, skewness, kurtosis and Jarque-Bera. The dependent variable which is return on asset ratio shows a minimum value of 0.242115 and a maximum value of 3.225994 . The mean value of the dependent variable is 1.961074 and the standard deviation is 0.975762. This implies that there was high fluctuation in return on asset ratio for the years. It can be observed from Table 4.2 that all the variables have positive average values (means). It can be observed also that only return on asset ratio shows a sign of negative skewness while other variables showed sign of positive skewedness. All the variables except account payable ratio have high kurtosis.

\begin{tabular}{|c|c|c|c|c|}
\hline & ROAR & DR & ARR & APR \\
\hline Mean & 0.404620 & 0.152097 & 1.224138 & 0.087128 \\
\hline Median & 0.420184 & 0.134224 & 1.246558 & 0.086394 \\
\hline Maximum & 0.538042 & 0.294610 & 1.579778 & 0.131958 \\
\hline Minimum & 0.240945 & 0.026949 & 0.937433 & 0.044004 \\
\hline Std. Dev. & 0.093523 & 0.073587 & 0.214281 & 0.026047 \\
\hline Skewness & -0.405101 & 0.347947 & 0.144807 & 0.230309 \\
\hline Kurtosis & 2.096000 & 2.916682 & 1.779385 & 2.501208 \\
\hline Jarque-Bera & 0.614019 & 0.204671 & 0.655740 & 0.192068 \\
\hline Probability & 0.735644 & 0.902727 & 0.720457 & 0.908433 \\
\hline Sum & 4.046199 & 1.520973 & 12.24138 & 0.871284 \\
\hline Sum Sq. Dev. & 0.078719 & 0.048735 & 0.413246 & 0.006106 \\
\hline Observations & 10 & 10 & 10 & 10 \\
\hline
\end{tabular}

Table 9: Descriptive Sta tistics (Nestle Nigeria Plc)

The study conducted the descriptive statistics of the relevant variables involved. Table 4.2 illustrates vividly these statistics. It shows total number of observations, mean, median, maximum, minimum, standard deviation, skewness, kurtosis and Jarque-Bera. The dependent variable which is return on asset ratio shows a minimum value of 0.240945 and a maximum value of 0.538042 . The mean value of the dependent variable is 1.961074 and the standard deviation is 0.975762. This implies that there was high fluctuation in return on asset ratio for the years. It can be observed from Table 4.2 that all the variables have positive average values (means). It can be observed also that only return on asset ratio shows a sign of negative skewness while other variables showed sign of positive skewedness. All the variables except account payable ratio have high kurtosis.

4.2. Unit Root Test

\begin{tabular}{|c|c|c|c|c|}
\hline & ADF & cv@ 5\% & Probability & Inference \\
\hline ROAR & -2.297036 & -1.995865 & 0.03671 & $\mathrm{I}(1)$ \\
\hline DR & -3.185019 & -2.021193 & 0.0077 & $\mathrm{I}(1)$ \\
\hline ARR & -2.939747 & -2.021193 & 0.0111 & $\mathrm{I}(2)$ \\
\hline APR & -3.971976 & -3.403313 & 0.0255 & $\mathrm{I}(2)$ \\
\hline
\end{tabular}

Table 10: Unit root test (Nigerian Brewery Plc) 
Table 10 showed that return on asset ratio and debt ratio became stationary at first difference while account receivable ratio and account payable ratio became stationary at second difference.

\begin{tabular}{|c|c|c|c|c|}
\hline & ADF & cv@ 5\% & Probability & Inference \\
\hline ROAR & -4.585737 & -3.403313 & 0.0127 & $\mathrm{I}(2)$ \\
\hline DR & -5.669509 & -1.995865 & 0.0002 & $\mathrm{I}(1)$ \\
\hline ARR & -2.023346 & -2.006292 & 0.0486 & $\mathrm{I}(1)$ \\
\hline APR & -4.460107 & -1.995865 & 0.0008 & $\mathrm{I}(\mathrm{I})$ \\
\hline
\end{tabular}

Table 11: Unit Root Test (Guinness Nigeria Plc)

Table 11 showed that return on asset ratio became stationary at second difference while debt ratio, account receivable ratio and account payable ratio became stationary at first difference.

\begin{tabular}{|c|c|c|c|c|}
\hline & ADF & cv@ 5\% & Probability & Inference \\
\hline ROAR & -4.677682 & -4.450425 & 0.0411 & $\mathrm{I}(1)$ \\
\hline DR & -10.43339 & -4.450425 & 0.0006 & $\mathrm{I}(2)$ \\
\hline ARR & -4.230339 & -3.403313 & 0.0189 & $\mathrm{I}(2)$ \\
\hline APR & -2.072777 & -2.006292 & 0.0445 & $\mathrm{I}(2)$ \\
\hline
\end{tabular}

Table 12: Unit root test (Nestle Nigeria Plc)

Table 12 showed that return on asset ratio became stationary at first difference while debt ratio, account receivable ratio and account payable ratio became stationary at second difference.

\subsection{Regression Analysis}

\begin{tabular}{|c|c|c|c|c|}
\hline \multicolumn{5}{|c|}{$\begin{array}{c}\text { Dependent Variable: ROAR } \\
\text { Method: Least Squares } \\
\text { Date: 10/ 10/ 19 Time: 09:27 } \\
\text { Sample: 2007- 2016 } \\
\text { Included observations: } 10\end{array}$} \\
\hline Variable & Coefficient & Std. Error & t-Statistic & Prob. \\
\hline $\mathrm{C}$ & 3.833565 & 2.852169 & 1.344088 & 0.2275 \\
\hline$\overline{\mathrm{DR}}$ & 6.681031 & 4.849462 & 1.377685 & 0.2175 \\
\hline ARR & -5.373218 & 3.724673 & -1.442601 & 0.1992 \\
\hline APR & -0.589105 & 0.833725 & -0.706594 & 0.5063 \\
\hline R-squared & 0.327810 & \multicolumn{2}{|c|}{ Mean dependent var } & 0.755356 \\
\hline Adjusted R-squared & -0.008285 & \multicolumn{2}{|c|}{ S.D. dependent var } & 1.602153 \\
\hline S.E. of regression & 1.608776 & \multicolumn{2}{|c|}{ Akaike info criterion } & 4.077999 \\
\hline Sum squared resid & 15.52897 & \multirow{2}{*}{\multicolumn{2}{|c|}{$\begin{array}{l}\text { Schwarz criterion } \\
\text { Hannan-Ouinn criter. }\end{array}$}} & 4.199033 \\
\hline Log likelihood & -16.39000 & & & 3.945225 \\
\hline F-statistic & 0.975349 & \multicolumn{2}{|c|}{ Durbin-Watson stat } & 1.866455 \\
\hline Prob(F-statistic) & 0.464064 & & & \\
\hline
\end{tabular}

Table 13: Ordinary Least Square (Nigerian Brewery Plc)

Table 4:4.1 shows that the R2 which is 0.327810 is about 32\%, therefore it does not have a poor goodness of fit. The F-statistic which is 0.975349 is less than 2.5 while its probability value is more than $5 \%$, it is therefore concluded that it is statistically insignificant. The Durbin-Watson statistic is approximately 2 , therefore there is no autocorrelation in the model implying it can be used to make a meaningful analysis. 


\begin{tabular}{|c|c|c|c|c|}
\hline \multicolumn{5}{|c|}{$\begin{array}{l}\text { Dependent Variable: ROAR } \\
\text { Method: Least Squares } \\
\text { Date: 10/ 10/ } 19 \text { Time: 09:40 } \\
\text { Sample: } 20072016 \\
\text { Included observations: } 10\end{array}$} \\
\hline Variable & Coefficient & Std. Error & t-Statistic & Prob. \\
\hline $\mathrm{C}$ & 2.283701 & 3.652616 & 0.625223 & 0.5548 \\
\hline DR & -4.557540 & 1.635699 & -2.786294 & 0.0317 \\
\hline ARR & 0.755770 & 2.600634 & 0.290610 & 0.7811 \\
\hline APR & 0.149045 & 0.240723 & 0.619156 & 0.5586 \\
\hline R-squared & 0.651562 & \multicolumn{2}{|c|}{ Mean dependent var } & 1.961074 \\
\hline Adjusted R-squared & 0.477343 & \multicolumn{2}{|c|}{ S.D. dependent var } & 0.975762 \\
\hline S.E. of regression & 0.705428 & \multicolumn{2}{|c|}{ Akaike info criterion } & 2.429149 \\
\hline Sum squared resid & 2.985768 & \multicolumn{2}{|c|}{ Schwarz criterion } & 2.550183 \\
\hline Log likelihood & -8.145745 & \multicolumn{2}{|c|}{ Hannan-Quinn criter. } & 2.296375 \\
\hline F-statistic & 3.739899 & \multicolumn{2}{|c|}{ Durbin-Watson stat } & 1.474683 \\
\hline Prob(F-statistic) & 0.079453 & & & \\
\hline
\end{tabular}

Table 14: Ordinary Least Square (Guinness Nigeria Plc)

Table 4:4.2 shows that the $\mathrm{R}^{2}$ which is 0.651562 is about $65 \%$, therefore it has a goodness of fit. The F-statistic which is 3.739899 is greater than 2.5 while its probability value being 0.079453 is less than $5 \%$, it is therefore concluded that it is statistically significant. The Durbin-Watson statistic is not approximately 2 , therefore there is autocorrelation in the model.

\begin{tabular}{|c|c|c|c|c|}
\hline \multicolumn{5}{|c|}{$\begin{array}{c}\text { Dependent Variable: ROAR } \\
\text { Method: Least Squares } \\
\text { Date: 10/ 10/ 19 Time: 09:59 } \\
\text { Sample: 2007- 2016 } \\
\text { Included observations: } 10\end{array}$} \\
\hline Variable & Coefficient & Std. Error & t-Statistic & Prob. \\
\hline $\mathrm{C}$ & 0.275000 & 0.252472 & 1.089227 & 0.3179 \\
\hline $\mathrm{DR}$ & 0.472448 & 0.421843 & 1.119963 & 0.3055 \\
\hline ARR & 0.118348 & 0.165886 & 0.713429 & 0.5024 \\
\hline APR & -0.999814 & 1.182958 & -0.845181 & 0.4304 \\
\hline R-squared & 0.547578 & \multicolumn{2}{|c|}{ Mean dependent var } & 0.404620 \\
\hline Adjusted R-squared & 0.321367 & \multirow{2}{*}{\multicolumn{2}{|c|}{$\begin{array}{l}\text { S.D. dependent var } \\
\text { Akaike info criterion }\end{array}$}} & 0.093523 \\
\hline S.E. of regression & 0.077044 & & & -1.999714 \\
\hline Sum squared resid & 0.035614 & \multicolumn{2}{|c|}{ Schwarz criterion } & -1.878680 \\
\hline Log likelihood & 13.99857 & \multicolumn{2}{|c|}{ Hannan-Quinn criter. } & -2.132488 \\
\hline F-statistic & 2.420653 & \multicolumn{2}{|c|}{ Durbin-Watson stat } & 0.806594 \\
\hline Prob(F-statistic) & 0.164309 & & & \\
\hline
\end{tabular}

Table 15: Ordinary Least Square (Nestle Nigeria Plc)

Table 4:10 shows that the $\mathrm{R}^{2}$ which is 0.547578 is about $55 \%$, therefore it has goodness of fit. The F-statistic which is 2.420653 is less than 2.5 while its probability value being 0.164309 is more than $5 \%$, it is therefore concluded that it is statistically insignificant. The Durbin-Watson statistic is not approximately 2 , therefore there is autocorrelation in the model.

\subsection{Test of Hypotheses}

\subsubsection{Hypothesis One}

\subsubsection{Step One}

Account payable ratio does not have a significant effect on the return o,n asset ratio of the productive firms in Nigeria.

\subsubsection{Step Two}

Ordinary Least Square is used in testing for the hypothesis. 
4.4.1.3. Step Three

\begin{tabular}{|c|c|c|c|c|}
\hline \multicolumn{5}{|c|}{$\begin{array}{c}\text { Dependent Variable: ROAR } \\
\text { Method: Least Squares } \\
\text { Date: 09/ 10/ 19 Time: 09:27 } \\
\text { Sample: 2007- 2016 } \\
\text { Included observations: 10 }\end{array}$} \\
\hline \multicolumn{5}{c|}{ Prob. } \\
\hline Variable & Coefficient & Std. Error & t-Statistic & 0.2275 \\
\hline C & 3.833565 & 2.852169 & 1.344088 & 0.2175 \\
\hline DR & 6.681031 & 4.849462 & 1.377685 & 0.1992 \\
\hline ARR & -5.373218 & 3.724673 & -1.442601 & 0.5063 \\
\hline APR & -0.589105 & 0.833725 & -0.706594 & 0.755356 \\
\hline R-squared & 0.327810 & Mean dependent var & 1.602153 \\
\hline Adjusted R-squared & -0.008285 & S.D. dependent var & 4.077999 \\
\hline S.E. of regression & 1.608776 & Akaike info criterion & 4.199033 \\
\hline Sum squared resid & 15.52897 & Schwarz criterion & 3.945225 \\
\hline Log likelihood & -16.39000 & Hannan-Quinn criter. & 1.866455 \\
\hline F-statistic & 0.975349 & \multicolumn{2}{|c|}{ Durbin-Watson stat } & \\
\hline Prob(F-statistic) & 0.464064 & \multicolumn{5}{|c|}{ Table 16 } \\
\hline
\end{tabular}

\subsubsection{Step Four}

Decision Rule: Reject the null hypothesis if the $t$ - statistics is greater than 2.5 and the probability value is less than $5 \%$.

\subsubsection{Step Five}

\subsection{Conclusion/ Decision}

Since the t-statistics of the debt ratio which is 1.344088 is less than 2.5 and the Pvalue is more than $5 \%$, the null hypothesis is accepted. It is therefore concluded that debt ratio does not have a significant effect on the return on asset ratio of the productive firms in Nigeria.

\subsubsection{Hypothesis Two}

\subsubsection{Step One}

Account receivable ratio does not have a significant effect on the return on asset ratio of the productive firms in Nigeria.

\subsubsection{Step Two \\ Ordinary Least Square is used in testing for the hypothesis.}

\subsubsection{Step Three}

\begin{tabular}{|c|c|c|c|c|}
\hline & $\begin{array}{r}\text { Dependent } \\
\text { Method: I } \\
\text { Date: 09/ 10/ } \\
\text { Sample: } \\
\text { Included ob }\end{array}$ & $\begin{array}{l}\text { riable: R0 } \\
\text { st Square } \\
\text { Time: 0 } \\
\text { 07-2016 } \\
\text { rvations: }\end{array}$ & & \\
\hline Variable & Coefficient & Std. Error & t-Statistic & Prob. \\
\hline $\mathrm{C}$ & 3.833565 & 2.852169 & 1.344088 & 0.2275 \\
\hline DR & 6.681031 & 4.849462 & 1.377685 & 0.2175 \\
\hline ARR & -5.373218 & 3.724673 & -1.442601 & 0.1992 \\
\hline APR & -0.589105 & 0.833725 & -0.706594 & 0.5063 \\
\hline R-squared & 0.327810 & \multicolumn{2}{|c|}{ Mean dependent var } & 0.755356 \\
\hline Adjusted R-squared & -0.008285 & \multicolumn{2}{|c|}{ S.D. dependent var } & 1.602153 \\
\hline S.E. of regression & 1.608776 & \multicolumn{2}{|c|}{ Akaike info criterion } & 4.077999 \\
\hline Sum squared resid & 15.52897 & \multicolumn{2}{|c|}{ Schwarz criterion } & 4.199033 \\
\hline Log likelihood & -16.39000 & \multirow{2}{*}{\multicolumn{2}{|c|}{$\begin{array}{l}\text { Hannan-Quinn criter. } \\
\text { Durbin-Watson stat }\end{array}$}} & 3.945225 \\
\hline F-statistic & 0.975349 & & & 1.866455 \\
\hline Prob (F-statistic) & 0.464064 & \multicolumn{2}{|c|}{ Durbin-Watson stat } & \\
\hline
\end{tabular}

Table 17 


\subsubsection{Step Four}

Decision Rule: Reject the null hypothesis if the $t$ - statistics is greater than 2.5 and the probability value is less than $5 \%$.

\subsubsection{Step Five}

\subsection{Conclusion/ Decision}

Since the t-statistics of the debt ratio which is 1.377685 is less than 2.5 and the $P$ value which is 0.1992 is more than $5 \%$, the null hypothesis is accepted. It is therefore concluded that Account receivable ratio does not have a significant effect on the return on asset ratio of the productive firms in Nigeria.

\subsubsection{Hypothesis Three}

\subsubsection{Step One}

Account payable ratio does not have a significant effect on the return on asset ratio of the productive firms in Nigeria.

\subsubsection{Step Two}

Ordinary Least Square is used in testing for the hypothesis.

\subsubsection{Step Three}

\begin{tabular}{|c|c|c|c|c|}
\hline \multicolumn{5}{|c|}{ Dependent Variable: ROAR } \\
\hline \multirow{2}{*}{\multicolumn{5}{|c|}{$\begin{array}{l}\text { Method: Least Squares } \\
\text { Date. } 09 / 10 / 19 \text { Time. } 09 \cdot 27\end{array}$}} \\
\hline & \multicolumn{4}{|c|}{ Date: 09/10/19 Time: 09:27 } \\
\hline \multicolumn{5}{|l|}{ Sample: 20072016} \\
\hline \multicolumn{5}{|c|}{ Included observations: 10} \\
\hline Variable & Coefficient & Std. Error & t-Statistic & Prob. \\
\hline $\mathrm{C}$ & 3.833565 & 2.852169 & 1.344088 & 0.2275 \\
\hline$\overline{\mathrm{DR}}$ & 6.681031 & 4.849462 & 1.377685 & 0.2175 \\
\hline ARR & -5.373218 & 3.724673 & -1.442601 & 0.1992 \\
\hline APR & -0.589105 & 0.833725 & -0.706594 & 0.5063 \\
\hline R-squared & 0.327810 & \multicolumn{2}{|c|}{ Mean dependent var } & 0.755356 \\
\hline Adjusted R-squared & -0.008285 & \multicolumn{2}{|c|}{ S.D. dependent var } & 1.602153 \\
\hline S.E. of regression & 1.608776 & Akaike i & criterion & 4.077999 \\
\hline Sum squared resid & 15.52897 & \multicolumn{2}{|c|}{ Schwarz criterion } & 4.199033 \\
\hline Log likelihood & -16.39000 & \multirow{2}{*}{\multicolumn{2}{|c|}{$\begin{array}{l}\text { Hannan-Quinn criter. } \\
\text { Durbin-Watson stat }\end{array}$}} & 3.945225 \\
\hline F-statistic & 0.975349 & & & 1.866455 \\
\hline Prob(F-statistic) & 0.464064 & \multicolumn{2}{|c|}{ Durbin-Watson stat } & \\
\hline
\end{tabular}

Table 18

\subsubsection{Step Four}

Decision Rule: Reject the null hypothesis if the $\mathrm{t}$ - statistics is greater than 2.5 and the probability value is less than $5 \%$.

\subsubsection{Step Five}

\subsection{Conclusion/ Decision}

Since the t-statistics of the debt ratio which is -0.706594 is less than 2.5 and the Pvalue which is 0.5063 is more than $5 \%$, the null hypothesis is accepted. It is therefore concluded that account payable ratio does not have a significant effect on the return on asset ratio of the productive firms in Nigeria.

\section{Summary of Findings, Conclusions and Recommendations}

\subsection{Findings}

- The study discovered that debt ratio does not have a significant effect on the return on asset ratio of the productive firms in Nigeria. This is due to the fact that the t-statistics of the debt ratio which is 1.344088 is less than 2.5 and the Pvalue is more than $5 \%$.

- The study also found out that account receivable ratio does not have a significant effect on the return on asset ratio of the productive firms in Nigeria. This is based on the premise that the t-statistics of the debt ratio which is 1.377685 is less than 2.5 and the Pvalue which is 0.1992 is more than $5 \%$.

- Finally, the study found out that account payable ratio does not have a significant effect on the return on asset ratio of the productive firms in Nigeria. This is due to the fact that the t-statistics of the debt ratio which is 0.706594 is less than 2.5 and the Pvalue which is 0.5063 is more than $5 \%$. 


\subsection{Conclusion}

The study concluded that for Nigerian brewery Plc the return on asset ratio and debt ratio were stationary at first difference while account receivable ratio and account payable ratio became stationary at second difference.

For Guinness Nigeria Plc the return on asset ratio was stationary at second difference while debt ratio, account receivable ratio and account payable ratio became stationary at first difference.

And for Nestle Nigeria Ltd the return on asset ratio was stationary at first difference while debt ratio, account receivable ratio and account payable ratio became stationary at second difference.

\subsection{Recommendation}

Base on the analysis of data and the findings of this research, the following recommendation were made

- To encourage credit facilities in a brewery firm the sales department of the firm must have easy to understand credit policy which will encourage the customers or client to accept their credit facilities without being bias and it will in return yield more profit to them. For the growth of any organization there must be a policy (credit policy) which attracts the customers more to the firms' product, thereby the sales department are expected to make a clear and flexible knowledge understanding of the credit policy towards their customers, this will attract the sales revenue to the firm,

The firm should work hard to achieve a high debtor turnover; the firm can achieve this by giving discount to their debtor's base on their durations of payment

- The rate of credit sales should be increased to loyal customers only.

- Credit policy should be adjusted from time to time on the basis of the characteristics of business firmsto observe, evaluate and regulate.

\section{References}

i. Adewurumi, W (2011). "A Survey of Lending Concepts principle and their Implications for Banker in Nigerian". Journals of the Nigerian Institute of Bankers, 21 (12), 3 - 9.

ii. Afolabi, I. (2011) Monetary Economic, Ibadan: Heineman Educational Books Plc.

iii. Anthony, R. N. (2013), Management Accounting, New York: McGraw-Hill.

iv. Donald, E. and Penne, A (2009) Intermediate Accounting. 2nd Ed. USA Willey Hamitton.

v. Donaldson, T.H. (2007). "Banking for a going concern principle of sound Lending". Journal of Nigerian Institute of Bankers, 4 (12), 22 - 35.

vi. Egginton, O.A. (2010). Accounting for the Lending Banker, London. Longman Group Ltd.

vii. Emery, D. (2010), Corporate Financial Management, New Jersey: Pearson, Prentice Hall.

viii. Eugene, F. B. (2012). Fundamentals of Financial Management, Sixth edition, Dryden Press, Illinois, U.S.A

ix. Foulks, L. (2008). Financial Management and Control, London: FTC Fouls Lynch Publications

x. Kakuru, J. (2011). Financial Decisions and the Business, 2nd edition, Kampala: The business publishing group.

xi. Majeed S., Makki M.A., Saleem S. and Aziz T. (2013). "The Relationship of Cash Conversion Cycle and Operational performance of Firms: An Empirical Investigation of Pakistan Firms". Journal of Emerging Issues in Economics, Finance and Banking, 1 (1), 35-51.

xii. Mmamel, Z. U and Samuel, O (2010). Marketing Research Methodology: A Practical Approach. Enugu: John Jacob’s Publications Limited.

xiii. Maysami R. C. (2010) Understanding and Controlling Cash flow. London: Harper and Row Publishers.

xiv. Muoneke, D. U (2009) Management Accounting.Enugu: Splash Media Organization.

xv. Nasr M. and Raheman A. (2007). "Working Capital Management and Operational performance Case of Pakistan Firms". International Review of Business Research Papers", 3(1), 279-300.

xvi. Nilsen, J. (2012). Trade Credit and the Bank Lending Channel. Journal of Money, Credit and Banking, 10 (3). 29 - 33.

xvii. Nwaezeku, N. C. (2009). Theories and practice of Financial Management. Owerri: Ever Standard Publishers

xviii. Obida S. S. and Owolabi S. A. (2012). Liquidity Management and Corporate Operational performance: Case Study of Selected Manufacturing Companies Listed on the Nigerian Stock Exchange. Business Management Dynamics, 2 (2), 10-25.

xix. Ojeka, S. A. (2012). "Credit Policy and its effects on Liquidity: A study of selected Manufacturing companies in Nigeria", The Journal of Commerce, 3 (13), 10- 19.

xx. Okolie, A. O. (2012), Accounts Payable Management in a corporation Organization. Enugu: Abic Books and Equipment.

xxi. Orjih, J. and Okafor, F (2012) Financial Institutions Operations, Regulations and Innovations, Enugu Sipah Media Organisation

xxii. Omuya, J.O. (2008). Frank woods Business Accounting: West African Edition, London Group Ltd UK.

xxiii. Owolabi, S. A. and Obida, S. S, (2012), Business Management Dynamics, New York: McGraw Hill Inc.

xxiv. Pandy, I.M. (2012). Financial Credit Management: Vicar Publishing House, New Delhi Ramanoorthy, V.E (2007) Working Capital Management, IFMR Madra.

xxv. Solomon, E. and Pringle,JJ. (2009) An introduction to Financial Management. New Jersey: Prentice Hall

xxvi. Smith, K.V. (2015). Management of working capital. New York: West African Publishing Company.

xxvii. Western, J. and Brigham, E. (2006) Managerial Finance, lIIunas, Dryden Press. 